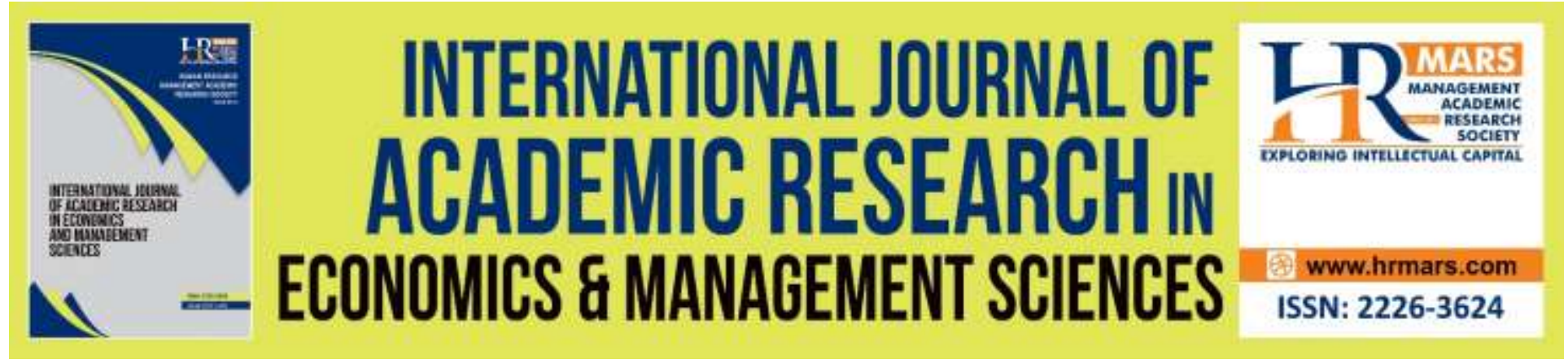

\title{
A Review on Impact of OFDI in Malaysia as a Home Country Since Malaysian Firms Going Global: Time to Accelerate or Slowdown
}

\section{F.A. Hira, Rafidah Othman, Theresa C. F Ho, Beni Widarman Yus Kelana}

To Link this Article: http://dx.doi.org/10.6007/IJAREMS/v8-i3/6561 DOI:10.6007/IJAREMS/v8-i3/6561

Received: 03 September 2019, Revised: 29 September 2019, Accepted: 10 October 2019

Published Online: 27 October 2019

In-Text Citation: (Hira, Othman, Ho, Kelana, 2019)

To Cite this Article: Hira, F. A., Othman, R., Ho, T. C. F., Kelana, B. W. Y. (2019). A Review on Impact Of OFDI in Malaysia as a Home Country Since Malaysian Firms Going Global: Time to Accelerate or Slowdown . International Journal of Academic Research in Economics and Management Sciences, 8(3), 43-52.

\section{Copyright: @ 2019 The Author(s)}

Published by Human Resource Management Academic Research Society (www.hrmars.com)

This article is published under the Creative Commons Attribution (CC BY 4.0) license. Anyone may reproduce, distribute, translate and create derivative works of this article (for both commercial and non-commercial purposes), subject to full attribution to the original publication and authors. The full terms of this license may be seen

at: http://creativecommons.org/licences/by/4.0/legalcode

Vol. 8, No. 3, 2019, Pg. 43 - 52

http://hrmars.com/index.php/pages/detail/IJAREMS

JOURNAL HOMEPAGE

Full Terms \& Conditions of access and use can be found at http://hrmars.com/index.php/pages/detail/publication-ethics 


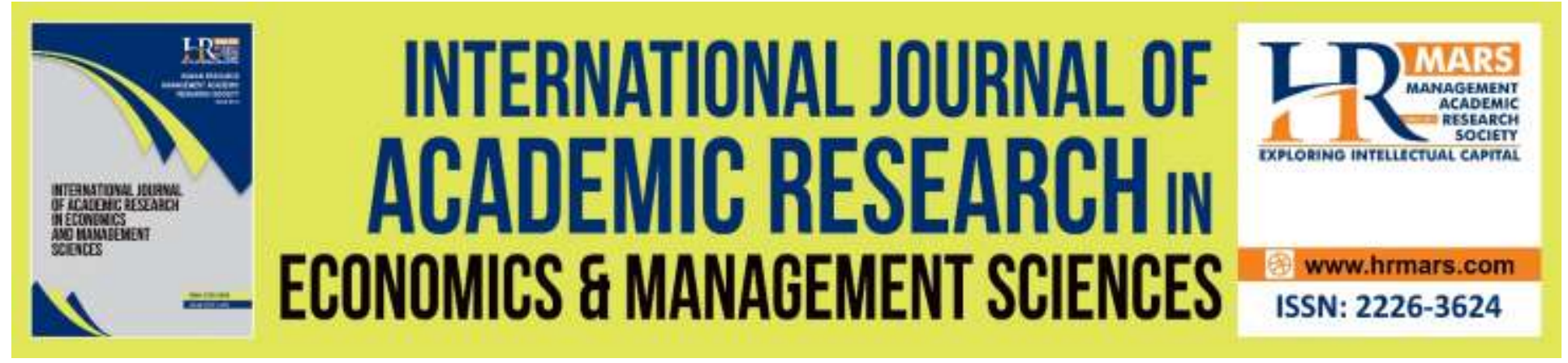

\title{
A Review on Impact Of OFDI in Malaysia as a Home Country Since Malaysian Firms Going Global: Time to Accelerate or Slowdown
}

\author{
F.A. Hira, Rafidah Othman, Theresa C.F Ho, Beni Widarman Yus \\ Kelana
}

Azman Hashim International Business School, Universiti Teknologi Malaysia, 54100 Kuala

Lumpur

\begin{abstract}
Abstrat
This paper goals to explore the role of global expansion of MNCs and impact of outward foreign direct investment (OFDI) on home county from Malaysian perspective. This study brought together the insights from previous studies on impacts of OFDI on home country benefit. Search was limited within paper published between 2010 to 2019 with special focus on OFDI in impact on development on Malaysia. Nevertheless, the study discloses the investment development path (IDP) theory hypothetically supports internationalization of Malaysian local firms as MNCs (Multinational Corporation) to conduct business activities overseas.

Keywords: OFDI, MNCs, Home-Country, Malaysia, Cross-Border Investment.

\section{Introduction}

Foreign Direct Investment (FDI) inflow has major contribution on the economic development of Malaysia. Scholars and policy makers has been focusing on inward flow of FDI in host country for years (Wong, 2010). Therefore, impact of inward FDI has been widely discussed and well documented. On the contrary noticeably fewer study has been directed on the impact of outward foreign direct investment (OFDI) in home country (Lim \& Teo, 2018). OFDI also documented as ODI (Outward direct investment) or DIA (Direct investment abroad). OFDI is a cross-border investment by home county firms (MNCs) to a host country economy. OFDI enables home country firms to hold substantial degree of control and influence on management of a firms' global activities while operating business in overseas.
\end{abstract}

In spite of noticeable increment on OFDI from 2007, data from 1995 to 2015 mentioned in Figure 1; illustrates that Malaysian OFDI improved only by $1.4 \%$ (3.5\% to $4.9 \%$ ). 
INTERNATIONAL JOURNAL OF ACADEMIC RESEARCH IN ECONOMICS AND MANAGEMENT SCIENCES Vol. 8, No. 3, 2019, E-ISSN: 2226-3624 @ 2019 HRMARS

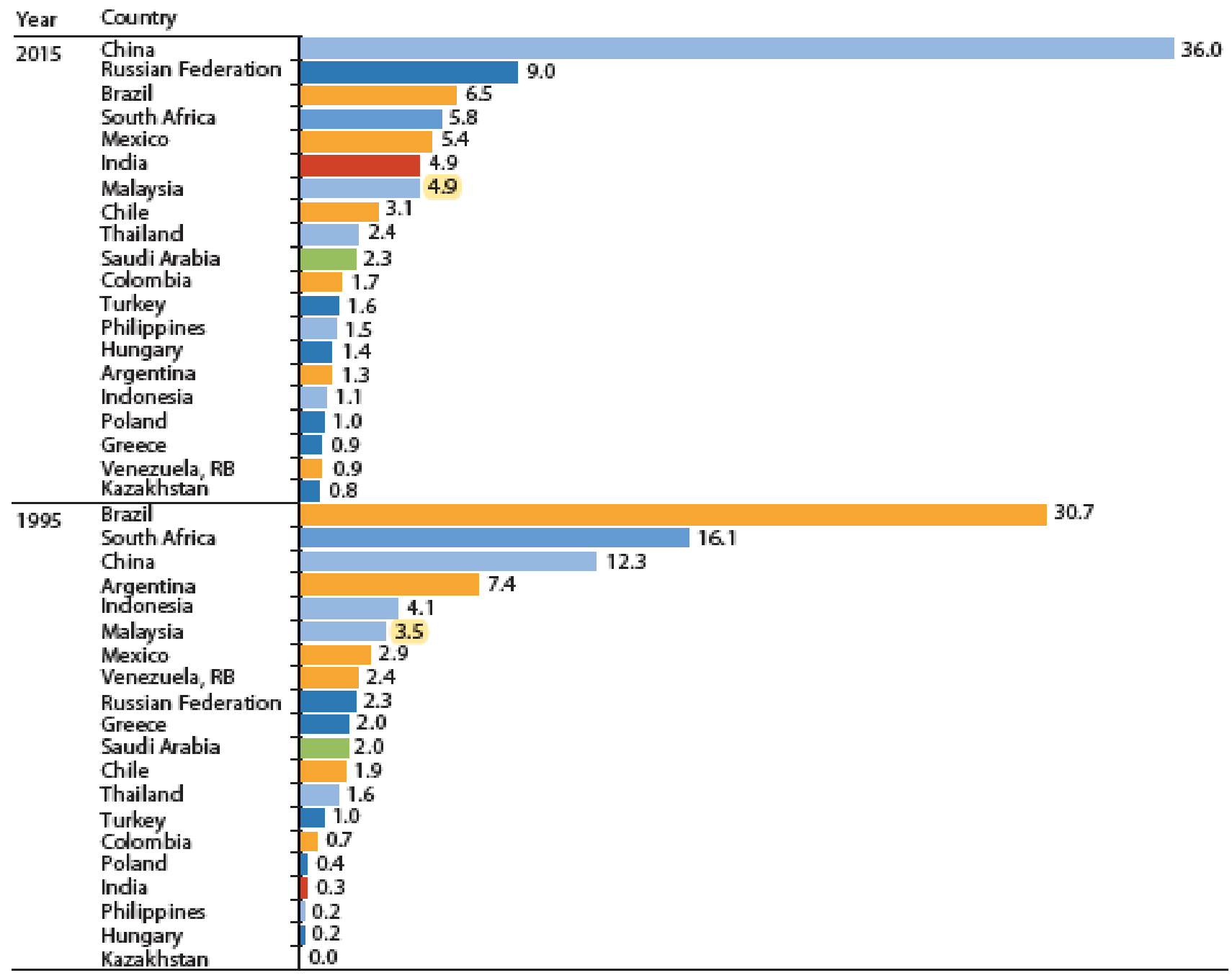

Share of total developing country OFDI stock (percent)

Region
$\begin{aligned} & \text { Sub-Saharan Africa } \\ & \square \text { South Asia }\end{aligned}$ Middle East and North Africa
$\square$ Europe and Central Asia $\quad$ East Asia and Pacific

Figure 1: Top developing country outward investors

Source: Perea and Stephenson (2017)

The graph is fluctuating and moving downwards from 2012 to 2017 as shown in the Figure 2 below. OFDI percentage change is negative from 2013 to 2017 for Malaysia. From 3015 to 2017 ,OFDI became moderate with average an average of around 34 billion annually that is $2.7 \%$ of GDP between 2015 and 2017. Therefore, research urged for more cautious measures on countries OFDI (BNM, 2018). 


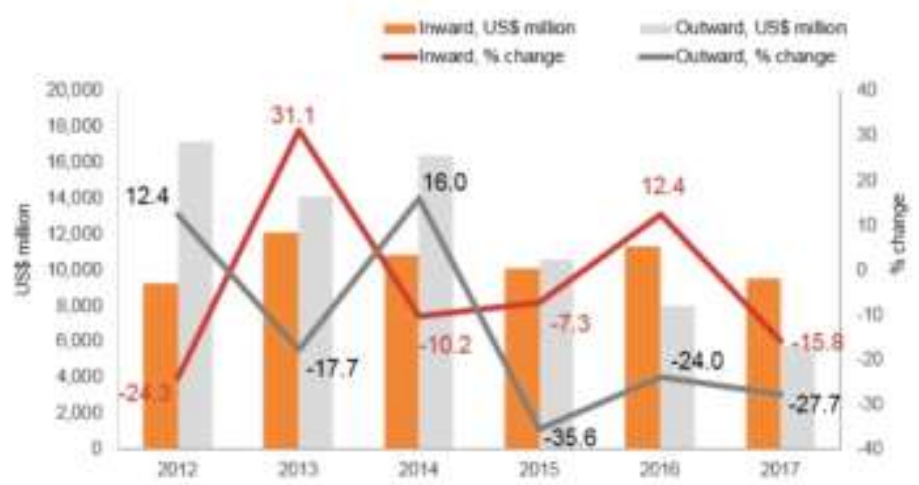

Figure 2: Foreign direct investment of Malaysia, 2012 - 2017

Source: HKTDC research (2019)

IDP (investment development path) model suggests a constant high economic growth within the domestic financial system may want to foster higher stage of economic development, where in domestic firms may prefer to concentrate on saturation within domestic market first before amplifying overseas operation. Considering Malaysia in stage three of IDP model, local firms should go global. Although, research argues that in this stage benefits are more firm-specific than country-specific. Malaysia being high-income developing country should actively seek for global expansion opportunities for local firms in search of resources as high income among general population increases resource and support system related cost. Hence, theoretically, the OFDI and home country economic development can run in parallel (Wong, 2010).

This study intends to analyses what are the financial and capacity building related impact of OFDI associated with home-grown Malaysian firms global expansion as MNCs. Whether OFDI has the potential to accelerate the growth of home country development in return. Consequently, this study also unpacks the developmental size of OFDI and the role of the country in developing a conducive surroundings to first nurture the firms, then inspire them to make investments overseas, and eventually hyperlink their outward investment to financial improvement returned within the home economy. Limited number of studies considered OFDI from developing country, specifically form Malaysian prospective (Chen \& Zulkifli, 2012). Hence, there is room for research and explore more on home country benefit from OFDI in light of those perspectives. Therefore, it is expected that this study will extend the body of existing literature. Malaysian firms global activity and OFDI is interrelated. Hence, this study will be helpful to explore a better insight on OFDI and its impact on Malaysia as a home country. This finding can assist policy maker to rethink and redesign on policies regarding facilitating OFDI flow from Malaysia.

\section{Research Question}

$\mathrm{RQ}_{1}$ : To what extend homegrown firm's outward investment is beneficial for home country from financial (including export) and capacity building (tangible and intangible) perspective?

$\mathrm{RQ}_{2}$ : To what extend Malaysia should fuel home grown firm's global activities throw accelerating investment on OFDI? 
INTERNATIONAL JOURNAL OF ACADEMIC RESEARCH IN ECONOMICS AND MANAGEMENT SCIENCES Vol. 8, No. 3, 2019, E-ISSN: 2226-3624 C 2019 HRMARS

\section{Research Objective}

$\mathrm{RO}_{1}$ : Developing proper understanding on OFDI current trend and from Malaysian perspective as a home country

$\mathrm{RO}_{2}$ : Identifying impact of OFDI on home country from financial (including export) and capacity building (tangible and intangible) prospective

\section{Insight from Literature Survey}

Inward FDI (foreign direct investment) to Malaysia is showing an enormous decreasing trend due to increased stiff competition from emerging economy like China, India. Malaysian homegrown firms are venturing in to new global market in search of benefits like increased profit margin, in such situation, where inward OFDI is growing in a sluggish rapidity, OFDI can be an alternative for economic growth. On the other hand, if outward FDI is a complementary to domestic investment, it stimulates local production. This can be seen that multinational firms exploring the new markets, importing intermediate inputs from affiliates abroad and producing final goods in foreign affiliates at lower costs, and accessing foreign technology. With the combination of foreign and local productions, it lowers the cost of production and increases the competitiveness of multinational firms. As a result, it would benefit the overall domestic market with the associated spillover effects to local firms (Herzer, 2010). Nonetheless, the impact of outward FDI on the development of a country depends on the absorption ability level of the home economy and the rate of technological gap between MNCs and non-multinational domestic firms (Denzer, 2011). Research suggests that OFDI has positive impact in the long-term on home countries benefit (Herzer, 2010).

OFDI can have both positive and negative impact on home country development depending on the nature of OFDI. According to Herzer (2010), in the occasion that OFDI is an alternative to domestic production, whilst local firm relocate their production activity overseas, it shrinks local output, employment, and economic growth as well in the short term. Alternatively, OFDI as a complementary activity to local investment, encourages local production. In other words, OFDI is a potential alternative to domestic investment. Therefore, policy should play vital role to shape OFDI activity as a complementary activity for home country development. Moreover, OFDI as an alternative, insists local firms to relocate manufacturing process overseas because of faded home funding opportunities. Considering OFDI as a complementary activity to domestic production, home country resources can be utilized to deliver output to the host country. Moreover, through increased OFDI activity MNCs may additionally vend better home output (Chen \& Zulkifli, 2012). Local firms with global footprint (MNCs) are exploring the new markets, importing semi finished goods from partners in overseas and producing finished commodities in foreign country at a lower costs, and and retrieving foreign technology. Combined method of production enables cost cutting in production phase and increases competitiveness in the industry. As a consequence, it would accelerate home country benefit as spill over effects to local MNCs (Herzer, 2010). However, according to Denzer (2011) "the impact of OFDI on the development of a country depends on the absorption ability level of the home economy and the rate of technological gap between MNCs and non-multinational domestic firms" 


\section{Financial Impact}

Within the literature, economic perspectives articulate pertaining to the viable impacts of OFDI for the betterment of home countries financial flourishing (Wong, 2010). Knoerich (2017), analyzed OFDI income data of few developing countries including Malaysia and mentioned that, "successful investments by nature yield quantifiable financial gains for the investing firms as they make profits overseas or generate other earnings." Figure 3 illustrates the ROI (Return of investment) on OFDI in 2011, where average ROI form home country is $5 \%$ in general.

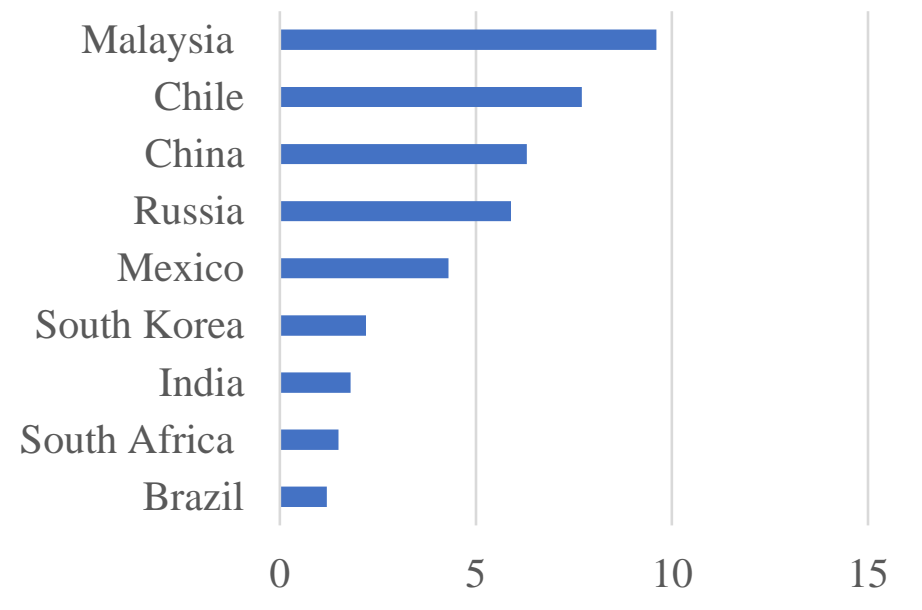

Figure 3: Foreign Direct investment income in 2011, USD billion

Source: Knoerich, 2017

The return from OFDI generally manage to overdo other kinds of investment returns (UNCTAD, 2013). Generally, a percentage of those income as ROI repatriates home country economy. In spite of fluctuating tendency of ROI from OFDI, it be significant (UNCTAD, 2013). Financial returns are shifted to the home country through several financial institutions like bank or via internal financial transaction within firm as "financial payment or transfer pricing" (Knoerich, 2017).

Monetary returns from OFDI occurs through earning generated from product and service delivery in host economy or export from the home country financial system. Moreover, OFDI towards developed economy has more significant impact than less advanced economies in case of alternate-assisting OFDI as a compliment for home countries economic activity. Chinese firms, for instance, increased investment on assembling operation and sales office in Europe that enabled them to export more product at a cheaper cost while the products are still being made in China. Taiwan has offshore business in Chania for the sales of their intermediate good. Therefore, the return of these businesses is going back to the home country in return. Moreover, cost saving is another form of monetary return that can be observable in more macrocosmic level. Local firms have the capability to assist other local suppliers through their activities in host country. The suppliers those who are unable to earn sufficient for themselves in local market, through the association with other local firm that has global operation, they can sale their product overseas and that return on profit is coming back to home country. This strategy not only helps boost healthy financial position for themselves but also supports other local small and medium enterprises to run their business profitably. Precise development assistances are 
realized when economic returns are transformed to be used in activities and tasks which can be crucial for domestic financial system improvement. Firms can expand activities through investing on research and development (R\&D), skill development etc. (Knoerich, 2017).

Exports acquiescent monetary returns are often serviced by a spread of industrial output and manufacturing in the domestic financial system, in step with an export-orientated increase approach. further to producing foreign exchange, this can create additional home employment so that some of the economic returns could be converted into wages, enhancing the opportunities and incomes of the population inside the much less advanced economic system. in the long run, a more monetary wealth at the enterprise and individual degrees contributes to raising domestic constant capital formation, country wide financial savings, consumption and tax sales (Knoerich, 2017). OFDI can potentially disseminate home countries' export growth. MNCs can trade for home country products to host countries using available specialized trade facilities. This strategy is helpful for significant improvement in market share (Pondicherry \& Tan, 2017).

\section{Impact on Tangible and Intangible Capacity}

Cross-border investment assists enhancement of a firms' human resource through improving skill of management, providing training (Emmanuel, 2014). Such interaction improves an organizational capacity as a whole (Malik \& Malik, 2013). Theoretically, OFDI is being supported from a local firms' perspective to seek for internationalization opportunity so that it can embark onto new managerial skills as well as technology advancement (Tchorek, 2016). Malaysian MNCs' global activity exposed some intangible capacity building regarding technology and knowledge transfer that occurred through the involvement in hospitality, financial service and tourism industry. Therefore, research suggests to facilitate OFDI as "intangible capability(transfers)" returns can be produced. Knowledge on "Know-How" transfers back to home country (BNM, 2018). Firms from less advanced economy can have significant benefit from "know-how" skills.

Alliances like merger, acquisition (M\&As), partnership with host country firms opens door to improved intangible capacity gaining through increasing knowledge base and asset upgradation occurs for the assets that are directly involved in operation. Hence, this process can be time consuming if the innovation happens from home country effort. For instance, Turkish firm Arçelik stablished alliance with European firms and entered PC business in 2004. The purchase of IBM's pc commercial enterprise in 2004 raised Lenovo's competitiveness internationally and increased market share via technological upgrading in first phase. Cross-border M\&As enables swift increase in know-how capacity of an organization. This understanding was the reason behind why in 2013 more than 55\% of global cross-border M\&As happened from developing and transition economy (UNCTAD, 2014). "Reverse forward linkages" may take place that can enable an investing firm to receive information on techniques, know-how, or training from its patron corporations from advanced economies. On the other hand, "Reverse backward linkages" offer opportunities for the procurement of superior producer items and other high-technology inputs from suppliers within the advanced economy where the funding is made. In addition to that labour turnover, properly-knowledgeable and excessive-skilled personnel employed in the superior host financial system bring new forms of (tacit) expertise and enjoy into the investing multinational. Skills received by means of firms investing overseas and transferred to the home 
economy may additionally unfold through know-how diffusion from HQs (headquarters) to different corporations there, facilitated by the reality that OFDI corporations are 'local' in origin, exhibit comparable traits and abilities to home country firms, cultivate robust home linkages and have a profound embeddedness of their home economy.

Furthermore, intangible capability returns might also recuperate requirements inside the domestic economic system, as MNCs introduce quality, environmental, labour, managerial and other requirements encountered overseas into their domestic operations. but even though the benefits for multinationals from "reverse' spill overs" and the diffusion of expertise and standards inside the home country financial system are workable from a theoretical factor of view, studies still wish to provide empirical affirmation of the effective results for less developed economies. eventually, the era of intangible capability returns isn't simply possible while firms make investments in more advanced economies. especially while OFDI faucets into low-fee, unskilled labour in economies which might be even less developed than the firms' country of origin (as would be the case with horizontal, trade-substituting OFDI). Capital- and talent-in depth manufacturing could start dominating output and exports, permitting 'white collar' employment to boom and wages to upward thrust with higher employee productivity. Such 'intangible functionality(upgrading)' returns have, as an example, been observed in Taiwan as soon as Taiwanese companies started offshoring labour intensive manufacturing to mainland China (Tsai, 2015). In sum, intangible capability returns assist upgrade corporations in much less advanced domestic economies. As this process eases technological deficiencies and lack of information within the less advanced economies from which the investments originate and supports technological development and catching up, there could be beneficial outcomes at the competitiveness and upgrading of home country economy and MNCs (Knoerich, 2017).

\section{Methodology}

This secondary research reviewed articles relevant to OFDI from developing country perspective with a specific focus on Malaysia. Search was limited to the scholarly papers published between 2010 to 2019 using google scholar in English. Total of 45 paper were reviewed for this systematic review. Keyword for search included for example; OFDI from developing country, OFDI in Malaysia, Outward foreign direct investment, etc.

\section{Result and Discussion}

Based on the empirical study, it can be stated that there is room for OFDI to be beneficial for home counties' financial and capacity building perspective. Although the benefits can only be visible in the long run, and can be more firm-specific. OFDI can be potentially beneficial if the country properly plans for internationalization strategy of firms. OFDI heavily dependent on macroeconomic environment, including factors like corporate tax rate and organizational nature. Precisely, excessive tax rate would prompt local firms to engage in investment abroad as a sign of escape response. This reflects that international expansion appears to be exit strategy from home country instead of entry strategy into foreign markets. The findings have some important implications on internationalization strategy of firms. According to previous studies government encouragement initiative has significant impact in internationalization of local MNCs. Therefore, government policies need to be more open toward OFDI to promote is as a supportive 
mechanism for home country development. Malaysian government was supportive towards OFDI during Dr. Mahathirs' previous term as the Prime Minister. He admonished local MNCs to "relocate overseas, go large scale and shift into high technology". As mentioned earlier that there is lack of comprehensive studies on impact OFDI. Therefore, this study suggests to conduct more research to specify the policy intervention that may potentially facilitate OFDI in a positive manner. We are living in a global village, in that scene that world is shrinking. Business venture are no more limited considering the geographical landmark. Alliance is being a popular and regular practice for MNCs. Industry revolution 4.0 also committed to bring changes. Considering these swift changes in global and national economic environment, OFDI can facilitate countries with development goals. Policy redesigning, rethinking is a must to extract the best benefit from OFDI for home country wellbeing.

\section{Limitations}

This study utilized available secondary data only. Due to time limitation, this study only focused on selected impact of OFDI on Malaysia and overlooked other potential factors that may have substantial impact.

\section{Conclusion}

OFDI is beneficial for home country to generate the economy although it may take sometimes for the effect to be visible. The impact of escape from tax burden to cooperation may hinder those potential investments to invest in the country. Furthermore, home countries to implement some of incentive and some mechanism to support them in the hosting countries to attract OFDI. To answer the 2 research question in this study, the evidence supported that homegrown firm's outward investment is beneficial for home country from financial and capacity building perspective. Furthermore, it will prosper local economic and improve employment. Therefore, Malaysia should fuel home grown firm's global activities through accelerating investment on OFDI. Hence, Malaysia should consider and encourage to modify their policies and openness toward promoting OFDI. This is aligning in the coming of Industry Revolution 4.0 (IR4.0), which committed to bring changes to local businesses. Therefore, policy redesigning, rethinking is a crucial movement for Malaysian to benefit from the revolution.

\section{Reference}

Aga, A. A. K. (2014). The impact of foreign direct investment on economic growth: A case study of Turkey 1980-2012. International Journal of Economics and Finance, 6(7), 71.

Emmanuel, O. N. (2014). Foreign direct investment and economic growth: The experience of CEMAC countries. Journal of Finance \& Economics, 2(1), 01-14.

Edwin, A. M. (2014). Foreign direct investment: A review from the Nigerian perspective. Research Journal of Business and Management, 1(3), 318-336.

Pondicherry, H., \& Tan, P. H. P. (2017). The determinants of foreign direct investment (FDI) in Singapore. Proceedings of the 12th Asia-Pacific Conference on Global Business, Economics, Finance and Social Sciences.

Malik, S., \& Malik, Q. A. (2013). Empirical analysis of macroeconomic indicators as determinants of foreign direct investment in Pakistan. IOSR Journal of Business and Management, 7(2), 77-82. 
INTERNATIONAL JOURNAL OF ACADEMIC RESEARCH IN ECONOMICS AND MANAGEMENT SCIENCES

Vol. 8, No. 3, 2019, E-ISSN: 2226-3624 C 2019 HRMARS

Knoerich, J. (2017). How does outward foreign direct investment contribute to economic development in less advanced home countries?. Oxford Development Studies, 45(4), 443459.

HKTDC Research . (2019). Retrieved 16 May, 26 , from http://emerging-marketsresearch. hktdc.com/business-news/article/Asia/Malaysia-Market Profile/mp/en/1/1X000000/1X003IG2.htm

Wong, K. (2010). Outward FDI and home country economic growth: a Malaysian case (No.56-10). Monash University, Department of Economics.

Goh, S. K., \& Wong, K. N. (2010). Malaysiaâ€ $€^{\text {TM }}$ s Outward FDI: The Effects of Host Market Size and Home Government Policy (No. 33-10). Monash University, Department of Economics.

Perea, J. R., \& Stephenson, M. (2017). Outward FDI from Developing Countries. Global Investment Competitiveness Report 2017/2018, 101.

Tchorek, G. (2016). Foreign Direct Investment and Investment Development Path. The Case of Visegrad Countries. Studia i Materiały, (2/2016 (22), cz. 2), 201-212.

Lim, G., \& Teo, J. K. (2018). Climbing the economic ladder: the role of outward foreign direct investment. Journal of Asian Public Policy, 1-18.

UNCTAD. Database: FDI outflows by Region and Economy, 1970-2010. New York and Geneva: United Nations. Chen, J. E., \& Zulkifli, S. A. M. (2012). Malaysian outward FDI and economic growth. Procedia-Social and Behavioral Sciences, 65, 717-722.

Herzer, D. (2010). Outward FDI and economic growth. Journal of Economic Studies , 37(5), 476494.

Denzer, A. (2011). The effects of outward FDI on economic growth a theoretical and empirical analysis (Doctoral dissertation). Eberhard Karls University Tuebingen, Germany.

BNM. (2018). Economics and Foreign Exchange Administration Departments March 2018. Retrieved 25 May, 2019 